\section{Produção de citocinas na esquistossomose mansônica humana e seus mecanismos regulatórios}

\begin{abstract}
A ação de IL-10, IFN- $\gamma$ e IL-12 na regulação da produção das citocinas do Tipo 1 e 2 foi estudada em vinte e seis pacientes esquistossomóticos com diferentes formas clínicas. Adicionalmente, foi avaliada a participação de alguns antígenos do $S$. mansoni na resposta imune da esquistossomose humana. Inicialmente, foram analisados os mecanismos regulatórios dependentes de IL-10 e IFN- $\gamma$ em sete pacientes com diagnóstico da forma aguda da esquistossomose e em dez pacientes com a forma crônica intestinal. Neste conjunto de experimentos, o sangue periférico total foi cultivado com estimulação de antígenos específicos (SWAP e SEA), mitógenos (PMA/ Iono) e anticorpos neutralizantes anti IL-10 e IFN- $\gamma$ IFN- $\gamma$ R. Os pacientes com a forma aguda da esquistossomose em relação à forma crônica intestinal responderam ao SEA e SWAP com maiores níveis de IFN- $\gamma$ e IL-5, enquanto os níveis de IL-10 foram semelhantes. Nos pacientes com a forma aguda e a forma crônica intestinal, a neutralização de IL-10 provocou um maior aumento na resposta de IFN- $\gamma$, após estímulo com SWAP em comparação com o SEA. A neutralização de IFN- $\gamma /$ IFN- $\gamma$ R, provocou um aumento na IL-10, sendo esse efeito mais notável em culturas estimuladas com SWAP, em pacientes com a forma aguda e com a forma crônica intestinal. A infecção aguda apresentou um aumento na produção de IFN- $\gamma$, enquanto que, a IL-10 tem um papel importante na forma aguda e que persiste durante a forma crônica. Em uma segunda etapa, foi estudada a regulação de IL-10 e IL-12 no baço e em células mononucleares do sangue periférico de nove pacientes com a forma crônica hepatoesplênica. Nesta etapa, analisando as células esplênicas, observamos que a produção de IFN- $\gamma$ estimulada por SEA foi baixa, sendo discretamente mais elevada após estímulo com SWAP. As citocinas IL-4 e IL-5 também foram baixas. Após neutralização de IL-10 e estímulo de SEA, houve um aumento
\end{abstract}

\section{Cytokine response and its regulatory mechanisms in human schistosomiasis mansoni}

The contribution of IL-10, IFN-g and IL-12 in the regulation of Type 1 and 2 cytokine responses was investigated in twenty-six schistosomiasis patients with different clinical conditions. In addition, the role of some $S$. mansoni antigens in the immune response against human schistosomiasis was evaluated. Initially, the regulatory mechanisms dependent on IL-10 and IFN- $\gamma$ were analyzed in patients with acute and chronic intestinal schistosomiasis. In these experiments, the whole peripheral blood was cultured with specific antigens (SEA and SWAP), mitogens (PMA/lono) and neutralizing antibodies anti-IL-10 and IFN- $\gamma / \mathrm{IFN}-\gamma \mathrm{R}$. The IFN- $\gamma$ and IL-5 cytokine pattern elicited by SEA and SWAP was higher in acute patients, while IL-10 was similar. In both acute and chronic patients, IL-10 neutralization markedly elevated SWAP-induced IFN- $\gamma$ in comparison with SEA-induced IFN- $\gamma$. The IFN- $\gamma / \mathrm{IFN}-\gamma \mathrm{R}$ neutralization up-regulated SWAP specific IL-10, in acute and chronic patients. These studies demonstrated that acute schistosomiasis is associated with a significant IFN- $\gamma$ response and that IL-10 contributes to the suppression of that response in early and chronic infection. Also, IL-10 and IL-12 regulation in spleen cells and PBMC from hepatosplenic patients were studied. There was little SEAspecific IFN- $\gamma$ in the spleens, but some SWAPinduced response was higher. The IL-4 and IL-5 responses were also low. IL-10 neutralization markedly restored SEA-specific IFN- $\gamma$. IL-12 upregulated IFN- $\gamma$ expression as well, although the increase was not antigen-dependent. In general, the cytokine responses in splenic cells and PBMC were similar, suggesting that there is no compartmentalized anatomic difference. Finally, Type 1 and 2 immune responses to the Sm15 and Sm13 antigens were evaluated. These antigens were not specific to induce production of cytokines. 
de IFN- $\gamma$. A IL-12 estimulou a produção de IFN-g em associação ou não com antígenos específicos. As respostas das citocinas em células esplênicas e seus mecanismos regulatórios foram similares em células mononucleares do sangue periférico, sugerindo que não há compartimentalização da resposta imune. Em uma última etapa, foram avaliadas as respostas imunes do Tipo 1 e 2 frente aos antígenos Sm15 e Sm13 de S. mansoni, produzidos na forma recombinante utilizando vetores de expressão procariotas. Esses antígenos recombinantes não foram capazes em experimentos preliminares de estimular especificamente a produção de citocinas.

Silvia Maria Lucena Montenegro

Tese apresentada ao Centro de Ciências da Saúde da Universidade Federal de Pernambuco para obtenção do Título de Doutor.

Recife, PE, Brasil, 1998. 